\title{
Trends in Business Communication Research, Teaching, and Academic Societies in Korean Higher Education
}

\section{Yeonkwon Jung}

\author{
Kansai Gaidai University, Osaka, Japan
}

Objectives: This paper investigates the contemporary academic trend in business communication in Korea. It tries to address the question of whether Korean business communicators are teaching business communication, and if they are, which kinds of business communication they teach, which traditions they follow, and how the teaching trend is projected to research trends in business communication in Korea.

Methods: This study first examines web content on business communication curricula and then conducts a content analysis of the websites of Korean communication associations as well as related qualitative interviews with professors whose academic interest is related to business communication in order to address some particular research questions.

Results: This study shows that business communication education in Korean universities (in communications departments) has a lack of variety (i.e., a predominance of organizational communication and media studies) and that actual business communication education (with an emphasis on language use in business contexts) is not done in courses titled Business Communication.

Conclusions: Nevertheless, interviewees expect a bright future for Korean business communication in both teaching and research (i.e., increasing the number of business communication courses to conduct a government-funded research project; establishing academic associations focusing on business and professional communication).

Key Words: Business communication, Korean business communication, Business communication curricula, Korean business communication associations, Workplace knowledge

\section{Introduction}

Business communication is an American academic discipline. Knight's (1999) seminal work on management communication

Received: Oct 3, 2017 Revised: Oct 30, 2017 Accepted: Nov 10, 2017 Corresponding author: Yeonkwon Jung

Kansai Gaidai University, 16-1 Nakamiyahigashino-cho, Hirakata-shi Osaka 573-1001, Japan

Tel: +81-72-805-2801, E-mail: yjung@kansaigaidai.ac.jp

This is an Open Access article distributed under the terms of the Creative Commons Attribution Non-Commercial License (http://creativecommons.org/licenses/by$\mathrm{nc} / 4.0 /$ ) which permits unrestricted non-commercial use, distribution, and reproduction in any medium, provided the original work is properly cited. Copyright $\odot 2018$ Korean Association for Business Communication. courses in American MBA programs illustrates the popularity of business communication in the U.S. Her study of 32 top-ranked MBA programs suggests that management communication is an important part of professional graduate management education. Her research samples show that 18 of the schools have required core courses in communication, and two other schools follow an integrated model and also offer electives; another nine offer electives only. A total of four schools also have writing proficiency requirements, and all four of those schools have core communication courses as well. Only three schools in her sample do not have any communication course offerings.

Following research from a local perspective, Knight (2005) 
investigates management communication in non-U.S. MBA programs. Although a study of top-ranked, full-time, global MBA programs suggests that management communication is indeed both an important focus and component in the curriculum, she claims that the methods of delivery do not follow any particular model, such as the common U.S. practice of a separate program or department. In a similar vein, required courses are found only at 10 of the 24 schools, including two at two schools. Elective communication courses are offered at eight schools, and related courses, those with a communication component, appear at all but one school.

This study aims to conduct introductory but extensive work on the contemporary academic trends in business communication in Korea in order to suggest potential steps Korean business communication research should take for future development. This research is motivated by the fact that despite remarkable economic growth in Korea, very little research has been conducted on Korean business communication (i.e., research on the local Korean language in the business context and business communication as business English, in particular) until relatively recently (Kenman, 2006). As Jung (2009) claims, this is apparently because the discipline of business communication is still new in Korea and, therefore, not academically prestigious. In view of this local situation, it is perhaps optimistic to expect active work in Korean business communication abroad. (cf. some exceptions: Jung, 2005a, b; Thomas, 1998). Despite the growing interest in business communication among "local" Korean scholars (i.e., the Korean Association for Business Communication [KABC] established in 2012: Suh, 2014), consequently, the lack of academic popularity of business communication in Korea makes it difficult to keep track of previous work or major transitions in Korean business communication (Jung, 2009).

Given the academic demand of Korean business communication, this project was conducted at the School of Media and Communication, Korea University, Seoul, Korea for a year (9/1/ 2016-8/31/2017) under the financial support of the Association for Business Communication's C.R. Anderson Research Funds (http://www.businesscommunication.org/page/anderson). The main research questions I plan to address are as follows:

Research Question 1: Are Korean business communicators teaching business communication?

Research Question 2: If they are, which kinds of business communication do they teach? (e.g., business communication, business discourse, professional communication, technical communication).

Research Question 3: Do they follow the American tradition or the European tradition, or do they follow both or neither in teaching business communication?
Research Question 4: How are the teaching trends projected to research trends in business communication in Korea?

This study hypothesizes that Korean business communication studies mainly follow the American tradition (i.e., communication in business, rather than communication for business (see Jung [2017a] for major differences between the American tradition and the European tradition), as the majority of communication-major faculty members in Korean universities are educated in American graduate schools, and their academic influence is given to graduate students working at Korean graduate schools. The types of data for the study are explained in the following section.

\section{Methods}

References to key institutions, individual/group research lists, journals, and professional organizations may provide starting points for gathering information and embarking on Korean business communication research from a local perspective. Following the research methods for a similar but pioneering study on pedagogy on business communication in higher education (Knight, 1999), this study first administers web research (and phone calls with administrators for the departmental registrar) to see the types of instruction done in Korean business communication and conducts related qualitative interviews with professors whose academic interests are related to business communication.

\section{Web Search}

The online research of this study includes both online research on types of business communication classes offered in Korean universities (35 universities excluding two-year junior colleges and graduate schools) and an analysis of websites of Korean communication associations to see research trends in business communication.

\section{Interview with Administrators}

Information on websites is verified by phone calls with administrators. Specifically, online research is followed up by semistructured interviews with Korean business communicators, which are prepared for a thicker description of preliminary findings of web research. Five (tenured) Korean professors (two of them from a department of communications and the others from a business school) are interviewed. The focus of the interview is on exploring who teaches the classes, how they teach them (types of data; data analysis method; types of textbook they use, etc.), and the future of Korean business communication. 


\section{Results}

Web Research

\section{Teaching Aspect}

Business communication is an umbrella term that includes four subdisciplines at the crossroads between communication and organization, such as management communication, organizational communication, corporate communication, and business communication (Miller, 1996). Louhiala-Salminen's (2009a: 308) definitions of the subdisciplines are as follows:

- Management communication investigates and teaches present and future managers. Its goal is to increase the effectiveness and efficiency of the communicative activities of managers.

- Organizational communication seeks to understand how the context of the organization influences communication processes and how people in the organization ascribe meanings to messages; it is also interested in how meanings are distorted or changed when messages are exchanged in both formal and informal networks.

- Corporate communication has evolved from what used to be known as public relations. Its main concern is a corporation's voice and image to its stakeholders.

- Business communication focuses on text and talk in the context of business. Given the American tradition of business communication research, a code of conduct for shaping workplace realities and articulating business strategic shifts is highlighted (Fairhurst, 2005).

The academic trend in Korean business communication is described in depth and classified into differences in academic trends in business communication across cultures - American business communication (i.e., business communication from the American approach) and European business communication (i.e., business communication from the European approach: business discourse and professional communication).

Miller's classification of subdisciplines of business communication led this research to investigate business communication curricula of communications departments of Korean universities, not business schools or language departments, as curricula from departments other than communications departments had an insufficient number of business communication courses that fit into the four subdisciplines of business communication. Some revisions to Miller's original classification are made in this study, as shown in Figure 1.

The main reason Miller's original categorization was revised is because the intercultural aspect of business communication (with no seeking to understand the form and function of English as a lingua franca in multinational or multicultural busi-

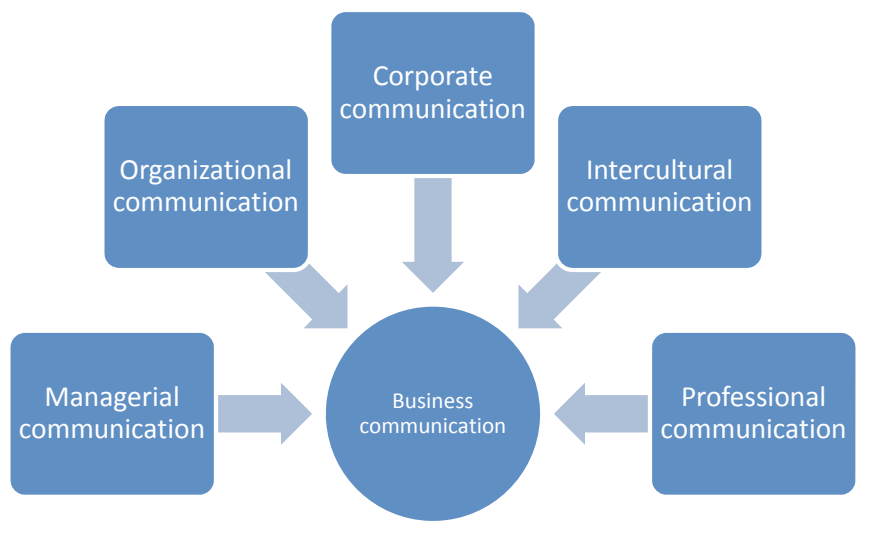

Figure 1. Tribes of business communication in the study (adapted from Jung 2017c).

nesses) has seen a growing interest in Korean universities, and such courses titled Business Communication, Technical Communication, English for Professional Purposes, and Health Communication are subordinated under the discipline of professional communication. Following the European business communication approach, professional communication works on communication for business. Generally speaking, professional communication accommodates communication for medical, legislative, business, and academic purposes (Bhatia, 1993). As Jung (2017a: 3) claims, accordingly, the size of its target in focus is much wider than that of the American business communication approach.

The classifications in Figure 1 show us some teaching trends in Korean business communication. Online research and phone calls with the departmental staff illustrate that Korean business communication curricula are mostly composed of corporate communication (PR-related courses) and organization communication (with particular reference to media studies in organization). These courses are very common in communications departments in Korea. Note that although health communication is a practice of professional communication in general, it seems closer to a PR course in Korea, as its approach is PR communication, rather than business discourse (e.g., doctor-patient talk).

As shown in Figure 1, managerial communication is also a part of business communication in the study, because few classes of speech, human, or interpersonal communication are accommodated under managerial communication. These teaching trends represent an effort to follow the American tradition of management communication curriculum in American MBA programs (Knight, 1999: 19). Korean academics may take the local perspective of business communication in its definition, as courses in PR communication and media studies hold priority among others. The following description of a business communication module in the communications department of a Kore- 
an university may also clarify that the scope of business communication in Korea is highly limited (i.e., Business communication "is" advertising, public relations, and marketing communication).

The Business Communication major deals with theory and practice in advertising, public relations, and marketing communication. Due to the rapidly changing media environment, society demands new communication skills. The business communication major aims to create 21 st century professionals who understand these trends and are able to empathize with consumers. In this course, we provide practical lessons in each field to enhance a basic understanding and a practical ability and an adaptation ability as well as basic theoretical lessons in order to accumulate basic knowledge required as a specialist in advertising, public relations, and marketing communication. In particular, various practical training opportunities in advertising, public relations, and marketing communication fields contribute to fostering practical communicators by providing students with an important basis for career choices and job preparation (emphasis is given with underlines).

As Knight (1999: 14) recognizes, contradictory information may often appear throughout a particular website, as course requirements might be updated in one place and not in another. For example, although some departments officially have business communication classes in the online description of their curriculum, telephone talks with administrators show that they actually have not maintained the courses or have replaced them with media-related courses. In this respect, unlike Knight's (1999, 2005) research, it is a bit problematic to quantify business communication courses in the study. A possible assumption for the reason for contradictory information on websites might be made in conjunction with the function of communication channels for delivering information, as Knight (1999: 14) claims that some websites serve primarily as marketing tools and not as resources for specific information.
Furthermore, even in those very few departments currently offering business communication courses (Business Communication; English for Professional Purposes), their actual content focuses on the Test of English for International Communication (TOEIC) listening comprehension/reading comprehension, and not "actual" business communication. Those few business communication courses focused on teaching TOEIC are ironically part of the core. The reason for adopting business communication as a required core course is not clear-cut if it is because business communication takes a prestigious position or the classes are for teaching TOEIC.

\section{Research Aspect}

Teaching trends in business communication in Korea are also projected to research trends in Korean business communication. Korean academic associations pertaining to the discipline of business communication are listed in Table 1.

Online research on the Korean academic associations mentioned above illustrates that the Korean Association for Secretarial Studies (KASS: http://www.kass.or.kr/) is popular among business communication academics. This is because the discipline of Secretarial Studies aims to develop administrative professionals equipped with professional knowledge and skills for office administration, information/system management, and business communication management needed in a business environment. Nevertheless, there is a certain limitation of theoretical application, as its members are mostly from two-year junior colleges.

As a partner association to KASS (of which members are mostly practitioners), the Korean Association of Administrative Professionals (KAAP: http://www.kaap.org/) offers business and communication training to practitioners (e.g., leadership communication; HRM; presentation skills; corporate communication; CRM; communication for convention industry; hospitality; [global] business manners and etiquette, among many oth-

Table 1. Korean academic associations pertaining to the discipline of business communication

\begin{tabular}{lcc}
\hline Name of association & Established date & Website \\
\hline The Korean Society for Journalism \& Communication Studies & $6 / 30 / 1959$ & https://www.comm.or.kr/ \\
Korean Communication Association & $3 / 5 / 1976$ & http://www.kcanet.or.kr/ \\
Korean Association for Secretarial Studies & $6 / 27 / 1992$ & http://www.kass.or.kr/ \\
Korean Association for Public Relations & $2 / 1997$ & http://www.kaspr.net/ \\
Korean Association of Teachers of English & 1/22/1965 (SIG since 2003) & http://www.kate.or.kr/ \\
- Special interest group (SIG): English for Specific Purposes (ESP) & & http://www.kabc.re.kr/ \\
Korean Association for Business Communication & $10 / 14 / 2011$ & http://espkorea.org/ \\
Korean Association for ESP* & $10 / 22 / 2016$ & \\
\hline
\end{tabular}

*This association is originated from the SIG of Korean Association of Teachers of English. 
ers). Despite the practical application of business communication, active research in business communication does not seem to be done by the members of either association. This project refers to Jeon's (2013) empirical study on the number of articles on business communication in the Journal of Secretarial Studies over two decades that was done in order to clarify inactive research trends of communication for business purposes in Korea. Her research illustrates that the number of articles on business communication was very low for two decades (1993-2012; 311 journals in total), such as $14.2 \%$ over the first half and $5.3 \%$ over the second half of the two decades.

Major Korean communication associations with relatively a long history still seem conservative regarding the discipline of business communication or the notion of business communication. For instance, the Korean Society for Journalism and Communication Studies (KSJCS, https://www.comm.or.kr/), the oldest and largest national association striving to promote journalism and communication scholarship, includes twenty SIGs to achieve its goal to advance the highest standard for education in journalism and communication-related fields. Each group represents a special subfield of communication processes and phenomena, such as advertising, international communication, advertising, culture and gender, media economics and business, media education, broadcasting and new media, media and society, media law and ethics, communication history, interaction, journalism, political communication, organizational communication, religion and communication, community journalism, communication policy, public relations, human communication, publication and communication, and science, health, environment \& risk communication. Although the SIGs include some subdisciplines of business or professional communication (e.g., organizational communication, international communication, PR, media studies, human communication, science, health, environment and risk communication), it is interesting to see that business communication is nowhere in its SIG.

\section{Interviews}

The outcome of web research clarifies the passive academic trend in Korean business communication. The lack of the academic popularity of business communication in Korea made it difficult to find interviewees for this project who work in a communications department and whose teaching and/or research interest lies in business communication.

Interview data illustrates that interviewees recognize that contemporary university education in Korea requires business communication as a discipline but that their departments have problems finding (part-time) instructors. It is interesting to see that the interviewed tenured Korean professors solely consider part- time (or contract) instructors for business communication courses. This perception raises interesting questions about the professional status of business communication faculty (e.g., their status, rank, and reward structure), which would be better addressed in a separate study. They also perceive the lack of variety in Korean business communication studies in that business discourse analysts who can deal with language data are extremely few in Korea, as clarified in the result of web research.

But they agree that the future of Korean business communication is bright, as Korean universities are gradually increasing the number of business and professional communication classes (e.g., human and/or speech communication in a business context; intercultural business communication; health communication) in order to increase the employment rates of their undergraduates while conducting the Advancement for College Education (known-as ACE) project. The ACE project accelerates the increase of business communication lectures as major or liberal arts subjects. The ACE project, also known as the 'good-teaching university' project, and which was established by the Ministry of Education and the Korean Council for University Education, has selected a number of universities since 2010 and has supported these universities for four years to discover and expand their leading model of college education (http://www.acec.or.kr/). Besides Korean Association for Business Communication becoming recently established with business and management focuses, from a research perspective, new academic associations focusing on business and professional communication are considered breakthroughs in practical English courses (e.g., Korean Association for ESP).

\section{Discussion}

The rapidly changing business world demands knowledge far beyond theory-orientation. Consequently, theory-based university knowledge no longer guarantees success in the workplace. Unlike conventional knowledge-based business communication studies, to meet this requirement, contemporary research work on business communication aims to offer knowledge far beyond tip-oriented business communication conventions (Jung, 2014, among many others).

Since business communication is not a conventional or automatic but rather a context-sensitive discipline, the latest business communication research emphasizes the role of context in organizing business communication materials (Jung, 2017a). Accordingly, it provides business communication learners with situational cases and scenarios in a variety of business and management settings to further develop their business communication skills. 
Due to globalization, for example, intercultural (business) communication is seeing growing interest in Korea. It is certain that shared knowledge between international business people such as national cultures is of vital importance for business success (Louhiala-Salminen, 2009b). However, if cultural differences are too emphasized for international business success, the function of business English as a lingua franca and sub-culture (e.g., corporate culture) is disregarded or devalued. Jung (2009) shows that 'cultural priorities' are influenced by the specific local or organizational context. He claims that organizational culture affects the business transactional stage, crisis management style, decision-making process, choice of address terms and subject pronouns, sensitivity to power, degree of imposition, and rhetorical structure (Jung, 2009: 369).

Likewise, Jung (2010) claims that it is through the realization of (in)directness that English as a lingua franca in business is affected by culture, but an exception can be made in cases where a differentiation situation is involved. It may be unclear if intercultural business communication classes in Korea are oriented toward a context in teaching business communication and English as a lingua franca in international business encounters, and they use teaching materials with a context-dependent approach. It would be better addressed in a separate study.

This study illustrates that teaching trends in Korean business communication (exclusively, in communication departments) seems far behind the mainstream in business communication studies worldwide. On the one hand, corporate communication and media relations have become increasingly important in business communication curricula in American and European universities. However, business communication is more than PR and media studies. The scope of the definition of business communication must be extended in Korea. This study only includes communications departments in the sample data in order to adapt Miller's categorization of business communication to the online research. Excluded from the scope of the study are issues related to the institutional/departmental home or location of communication courses (see Chang [2016] for the research on teaching trends in management communication at the 27 topranked business schools in Korea). An examination of business communication courses at business schools and English departments would be a useful complement to this study.

On the other hand, the written aspect of business communication seems to be important in American and European universities, as future managers will do a great deal of writing (Knight, 2005: 144). Unlike business communication programs in the US, the UK and other European countries, the teaching of writing does not seem to play a prominent role in business communication programs in Korea. It would be interesting to explore the fundamental reason for passive academic trends on business communication in Korea by tracking curricular changes in communication departments that are attributed specifically to their new standards or contemporary social demands. This investigation might be a stepping stone to fill the gap between the Korean academic tradition in business communication and their American and European counterparts.

\section{Conclusion}

Jung's (2017b, c) comparative research on Korean business communication pedagogy and professional needs in Korean organizations may make useful suggestions as guidelines for future research. It is a well-known fact that academic and business collaborative research illustrate the potential benefits and value for various interest groups and stakeholders (e.g., the government, businesspeople, business organizations, specialists in English for Specific Purposes [ESP] and Language for Specific Purposes [LSP] researchers and learners). Given the claim, Jung (2017b, c) explores communication knowledge that Korean business professionals should actually obtain in their workplaces. He tries to address the question of whether what Korean business communicators are teaching is what Korean business organizations and their workers need for business success, and if there is no match between the two, what the differences in needs are and how the differences are made. His findings are that the Korean business professionals' way of the interpretation of workplace knowledge illustrates that there is a significant gap between academics and practitioners in Korea. He claims that to fill the gap with the fundamental reason for heterogeneity between the two parties seems to be an urgent step before considering improving methods for business communication training. While there is hope and promise for the future, the field of the Korean business communication faces many obstacles and hurdles ahead.

\section{Acknowledgements}

Special thanks go to the Association for Business Communication to enable me to work on this project under the financial support of C.R. Anderson Research Funds. I also owe many thanks to Professor Youngmin Yoon, for her generous help while working on this project at Korea University, and Professor Hyejung Chang, President of the Korean Association for Business Communication, for her endless encouragement and constant moral support.

\section{References}

Bhatia, V. (1993). Analysing genre: Language use in professional set- 
tings. London: Longman.

Chang, H. (2016). Analysis of teaching trend on business communication. Proceedings of the Conference of Korean Association for Business Communication (pp. 22-28). Seoul, Korea.

Fairhurst, G. T. (2005). Reframing the art of framing: Problems and prospects for leadership. Leadership, 1(2), 165-185.

Jeon, J. H. (2013). An overview of articles on communication in the Journal of Secretarial Studies for two decades. Journal of Secretarial Studies, 22(3), 5-27.

Jung, Y. (2005a). The rhetorical structure of Korean business writing. In P. Gillaerts \& M. Gotti (Ed.), Genre Variation in Business Letters (347-368). Bern, Switzerland: Peter Lang.

Jung, Y. (2005b). Power and politeness in Korean business correspondence. In F. Bargiela-Chiappini, \& M. Gotti (Ed.), Asian Business Discourse(s) (pp. 291-312). Bern, Switzerland: Peter Lang.

Jung, Y. (2009). Korea. In F. Bargiela-Chiappini (Ed.), The Handbook of Business Discourse (pp. 356-371). Edinbugh, Scotland: Edinburgh University Press.

Jung, Y. (2010). Perceptions of (in)directness in Finnish and Korean business interaction. The Journal of International Business Communication, (69), 9-16.

Jung, Y. (2014). Basics of organizational writing: A critical reading approach. Bern, Switzerland: Peter Lang.

Jung, Y. (2017a). Professional writing: A discourse analysis approach. Singapore: Cengage Learning.

Jung, Y. (2017b). Research on business communication in Korea. Paper presented at the 15th Association for Business Communica- tion Asia-Pacific Conference, Hung Hom, Hong Kong.

Jung, Y. (2017c). Academic trend on business communication in Korea. Paper presented at the Korean Association for ESP conference, Seoul, Korea.

Kenman, L. (2006). A look at Korean business communication. Paper presented at 71st Annual convention of Association of Business Communication, San Antonio, TX.

Knight, M. (1999). Management communication in US MBA programs: The state of the art. Business Communication Quarterly, 62(4), 9-32.

Knight, M. (2005). Management communication in non-US MBA programs: Current trends and practices. Business Communication Quarterly, 68(2), 139-179.

Louhiala-Salminen, L. (2009a). Business communication. In F. Bargiela-Chiappini (Ed.), The Handbook of Business Discourse (pp. 305316). George Square, Edinburgh: Edinburgh University Press.

Louhiala-Salminen, L. (2009b). The macro \& the micro of IBC (international business communication). Paper presented at the Global Advances in Business Communication and Practices Conference, Ypsilanti, MI.

Miller, K. (1996). Who are we and what are we doing? Management Communication Quarterly, 10(1), 3-4.

Suh, Y. (2014). KABC: Past, Present, and Future. Paper presented at the 74th National Convention of Japan Business Communication Association, Kobe, Japan.

Thomas, J. (1998). Contexting Koreans: Does the high/low model work?. Business Communication Quarterly, 61(4), 1080-1099. 